\title{
Kartlegging av kosthold og livsstil
}

\author{
Sunn livsstil med et «hjertevennlig» kosthold beskytter mot karsykdom og diabetes. Likevel blir kosthold \\ og livsstil ofte nedprioritert under en legekonsultasjon. Ved bruk av et validert spørreskjema kan legen \\ på en rask og enkel måte kartlegge pasientens kosthold og livsstil og gi generelle kostholdsanbefalinger.
}

I klinisk praksis bør råd om kosthold og livsstil være en sentral del av behandlingen (1). På grunnlag av en god kostholdsanamnese kan legen gi individuelle råd om bl.a. inntak av fett, sukker, fiber, frukt og grønnsaker. Likevel blir informasjon om pasientens kosthold ofte ikke viet stor nok oppmerksomhet. Årsakene til dette kan være sviktende kunnskap og tidsnød, men også mangel på verktøy for å gjennomføre en god kostholdsanamnese $(1,2)$. Ved Lipidklinikken ved Oslo universitetssykehus, Rikshospitalet er det utarbeidet et enkelt spørreskjema, SmartDiet, for rask kartlegging av kosthold og livsstil. En evaluering av skjemaet er gjort i samsvar med validitetsstudier av andre kostskjemaer $(2,3)$.

SmartDiet har vært brukt forut for hver eneste konsultasjon i Lipidklinikken siden 2004. Skjemaet er blitt revidert to ganger for justering av matvareutvalget, siste gang i 2009 .

\section{Skjemaet}

Kostholdsdelen av SmartDiet består av 21 spørsmål, hvorav 14 er poenggivende. Det spørres om gjennomsnittlig bruk gjennom året av meieriprodukter, brød og andre kornprodukter, smør/margarin/olje, fisk- og kjøttprodukter på brødmat og til middag, majonesprodukter, frukt, bær og grønnsaker, belgvekster, poteter, ris og pasta, nøtter, egg, sukkerholdige matvarer/ drikke, godteri, kaker, snacks, kaffe og alkohol. For hvert poenggivende spørsmål er det tre svarkategorier for kvalitet samt angivelse av kvantitet av de mest brukte matvarene. Poeng fra hvert svar blir summert. Total poengsum gir et inntrykk av kostholdet generelt, og lav skår på ett eller flere svar indikerer punkter med forbedringsmuligheter.

Skjemaets livsstilsdel har fem spørsmål: høyde og vekt, måltidsfrekvens, bruk av røyk, snus og alkohol, fysisk aktivitet og bruk av kosttilskudd som f. eks. tran, omega-3 og vitaminer.

Spørreskjemaet består av to selvkopierende ark heftet sammen. Det ene arket beholder behandler, mens det andre, som også inneholder en beskrivelse av det anbefalte kostholdet, beholdes av pasienten.

Skjemaet er selvinstruerende. Pasienten fyller ut skjemaet i løpet av ti minutter på venterommet før konsultasjonen eller hjemme. Under konsultasjonen gjennomgås besvarelsen med pasienten, og det gis forslag til endringer.

\section{«I klinisk praksis bør råd om kosthold og livsstil vare en sentral del av behandlingen»}

\section{Erfaring fra bruk}

De kliniske ernæringsfysiologene ved Lipidklinikken har erfart at skjemaet gir en rask innføring $i$ en pasients kosthold og er en nyttig innfallsport til en individuell kostholdssamtale. For legene blir kostholdssamtalen en naturlig del av konsultasjonen.

Ved gjentatte utfyllinger av skjemaet med poengberegning kan man følge eventuelle endringer av kostholdet. Validitetsstudien viste at total poengsum fra skjemaet bør forbedres med minst tre poeng for å bety en endring i kostholdets sammensetning (3).

For nærmere å dokumentere hvor hensiktsmessig SmartDiet er i klinisk virksomhet gjennomførte vi i 2010 en spørreundersøkelse hos 104 pasienter som fortløpende kom til konsultasjon. De fleste syntes at skjemaet beskriver deres kosthold på en god måte og at gjennomgangen av besvarelsen under konsultasjonen var nyttig. Tre firedeler syntes det var lett å finne matvarene de selv bruker i spørreskjemaet. Skjemautfyllingen tok gjennomsnittlig $9^{1 / 2}$ minutt. De fleste (87\%) svarte at de hadde samme kosthold ved besvarelsen av skjemaet som ellers i året. To tredeler $(65,5 \%)$ ville gjennomføre kostholdsendringer etter gjennomgangen, mens de resterende fant kostholdet sitt så bra at det ikke var nødvendig å gjøre endringer.

\section{Anvendelse og begrensninger}

Selv om skjemaet hittil har vært beregnet til bruk ved Lipidklinikken, kan det også brukes ved kostholdsveiledning i allmennpraksis og spesialistpraksis og ved sykehusavdelinger/poliklinikker. Skjemaet er spesielt velegnet $\mathrm{i}$ behandling og forebygging av hjerte- og karsykdommer, diabetes og overvekt, men kan også brukes som et ledd i generell livsstilsveiledning (4). Skjemabesvarelsen gir et raskt innblikk i et individs kosthold, og viktige punktvise råd kan meddeles under konsultasjonen eller sendes skriftlig etterpå.

Angivelse av kostholdets kalorimengde og saltinntak er ikke mulig, og skjemaet har sine begrensninger ved behandling av overvekt. Mengdeangivelse av en del matvaregrupper gir likevel et godt inntrykk av kvantiteten av kaloririke matvarer.

I validitetsstudien var det for enkelte av forsøkspersonene store sprik mellom poenggivning fra spørreskjemaet og data fra kostregistreringen (3). Av enkeltspørsmålene viste grønnsaker og godteri dårligst samsvar, noe som bl. a. kan ha med definisjon av porsjonsenheter å gjøre. I likhet med erfaringen fra andre validitetsstudier har besvarelsen i spørreskjemaet en tendens til å gi et bedre inntrykk av kostholdets sammensetning enn hva kostregistrering forteller $(2,3,5)$.

Skjemaet har siden 2002 vært brukt til forskning ved enkelte sykehus og høyskoler i Norge. Det er oversatt til engelsk og dansk. I 2009 ble en kanadisk versjon lansert (5). Den kanadiske versjonen er mer omfattende og har kaloriberegning, men tar lengre tid å fylle ut enn vårt skjema.

Arne Svilaas
asvilaas@online.no
Ellen C. Strøm
Siril G. Johansen
Guri Vebenstad
Lipidklinikken
Medisinsk klinikk
Oslo universitetssykehus, Rikshospitalet
0027 Oslo
Tone Svilaas
Universitair Medisch Centrum
Groningen
Nederland
Leiv Ose
Lipidklinikken

Oppgitte interessekonflikter: Ingen

Litteratur

1. Pearson TA, Bloch R, Dorantes J et al. The rationale for renewed interest by physicians in nutrition. Curr Atheroscler Rep 1999; 1: 173-5.

2. Willett WC, Lenart E. Reproducibility and validity of food-frequency questionnaires. I: Willett WC, red. Nutritional epidemiology. Oxford: Oxford University Press, 1998: 101-47.

3. Svilaas A, Ström EC, Svilaas T et al. SmartDiet ${ }^{\mathrm{TM}}$, a health educational tool. Reproducibility and validity of a short food questionnaire for assessment of dietary habits. Nutr Metab Cardiovasc Dis 2002 12: $60-70$.

4. Kostråd for å fremme folkehelsen og forebygge kroniske sykdommer i Norge - Metodologi og vitenskapelig kunnskapsgrunnlag. Oslo: Helsedirektoratet, 2011.

5. Wiens L, Schulzer M, Chen $C$ et al. Reliability and validity of the SmartDiet Canadian version questionnaire. J Am Diet Assoc 2010; 100: 101 -5. 